\title{
EDUCATION AND MEDIA: CONTEMPORARY IMPLICATIONS IN THE ACADEMIC ROUTINE
}

\author{
Linda Nice Gamaํ, Cláudia Mara de Melo Tavares²
}

\begin{abstract}
${ }^{1}$ M.Sc. in Nursing. Adjunct Professor at the Maternal-Child Nursing and Psychiatry Department of the School of Nursing of Universidade Federal Fluminense (UFF). Niterói, Rio de Janeiro, Brazil. E-mail: nicegama@predial.cruiser.com.br

2 Ph.D. in Nursing. Head Professor at the Maternal-Child Nursing and Psychiatry Department of the School of Nursing of UFF. Niterói, Rio de Janeiro, Brazil. E-mail: claudiamarauff@gmail.com
\end{abstract}

\begin{abstract}
Digital technology development and interactive networks have undoubtedly reshaped the profile of subject matter in this century, creating demands and substantially redefining teaching and students' work in the use of media resources. This article identifies the assumptions of contemporary information and communication technologies and their didactic and pedagogical implications starting from mythological characters as argumentative resources, and discusses reductionist views that encompass issues related to education and technology. The purpose is to contribute to education in nursing, providing conceptual positions for the application of these technologies, with a critical evaluation of convergences and divergences.
\end{abstract}

DESCRIPTORS: Nursing education. Technologies. Hypermedia.

\section{EDUCAÇÃO E MÍDIAS: IMPLICAÇÕES CONTEMPORÂNEAS NO COTIDIANO ACADÊMICO}

RESUMO: O desenvolvimento das tecnologias digitais e das redes interativas, indubitavelmente, redimensiona o perfil do sujeito neste século, pois cria demandas e redefine substancialmente o trabalho docente e discente na utilização de recursos midiáticos. O presente artigo identifica os pressupostos contemporâneos das Tecnologias de Informação e Comunicação e suas implicações didático-pedagógicas partindo de personagens mitológicos, utilizando recursos argumentativos e problematizando as visões reducionistas que abarcam as questões relacionadas à educação e tecnologia. A proposta é contribuir com a educação em enfermagem como forma de proporcionar posicionamentos conceituais para aplicação destas tecnologias, avaliando criticamente suas aproximações e distanciamentos.

DESCRITORES: Educação em enfermagem. Tecnologias. Hipermídia.

\section{EDUCACIÓN Y LOS MEDIOS: IMPLICACIONES CONTEMPORÁNEAS EN EL ÁMBITO ACADÉMICO}

RESUMEN: El desarrollo de la tecnología digital y las redes interactivas, sin duda, redimensiona el perfil del sujeto en este siglo, creando demandas y sustancialmente redefiniendo lo trabajo de los profesores y los estudiantes en el uso de los recursos mediáticos. El artículo identifica los supuestos de Tecnologías de la Información y contemporánea y sus implicaciones didácticas y pedagógicas partiendo de personajes mitológicos como los recursos argumentativos y discute visiones reduccionistas que abarcan temas relacionados con la educación y la tecnología. La propuesta es contribuir a la educación en Enfermería, ofreciendo colocaciones conceptuales para la aplicación de estas tecnologías, y la evaluación crítica de sus aproximaciones y distanciamentos.

DESCRIPTORES: Educación en enfermería. Tecnologías. Hipermedia. 


\section{INTRODUCTION}

The vertiginous development of information and communications technologies (ICTs) and its didactic-pedagogical implications have resulted in great changes in current society, especially in the academic community. In the era of the Internet, the Web, hypermedia, and collaborative networks among other resources, education in nursing must consider such emergence in order to resignify its current modus operandi. Possibilities of information and communication, considerably mobile, based on anytime, anywhere, anyhow, call for multi-referenced and creative approaches in learning, with their dynamic, varied, and interactive resources of digital technology.

In that sense, we cannot turn our backs on changes that have arisen in education with the advent of ICTs, as they include different media and go beyond the limits of spatial, temporal, cultural, and curricular dimensions, providing subjects with interfaces. This is the interconnectivity era, in which interaction/interactivity stand out, as well as the opportunity to coexist with a diversity of ideas, dialogs, citizenship, and collaborative production work. Therefore, it is necessary to create pedagogical proposals that integrate mediating capabilities brought by ICTs and include different forms of communication provided by the digital technologies available, because they require some skills, distinctive pedagogical strategies, and the need to make school programs more flexible by creating spaces and time that suit the current demands of teachers and learners.

However, it is possible to observe an ideology of resistance in the process of accession to ICTs: those who advocate for their emancipating and beneficial features in education; and those who fear the "alien invasion" of machines and consider technological evolution as a source of various social problems in the current era. On the one hand, there is the desire to transcend, and on the other, a fear of subjection. The present study provides a critical and reflective analysis of ICTs and their implications and appropriations in the educational context.

\section{History: challenges to gods}

Myth, from Greek mythos (story), is an account of outstanding achievements whose supernatural (gods, monsters) or extraordinary (heroes) characters are used to explain the unknown, the enigmatic. Myth is a collective and historical creation of society itself and it provides a paradigm repository for the interpretation of human behavior. Myth is not an illusion or a fantasy. It needs to be examined and reflected upon, and this work will do so with two models of the Western mythological-literary tradition: Prometheus and Faust.

In Greek mythology, Prometheus was responsible for stealing fire from Zeus and giving it to mortal men, who gained wisdom and were able to master the technique of making fire. Upset, Zeus prepared his revenge on Olympus, by chaining the Prometheus to a cliff in the Caucasus. He sent an eagle to eat Prometheus's liver daily and, because he was a titan, his organ regenerated, so the destructive cycle restarted every day.

His suffering lasted for ages, until the Greek hero Heracles (Roman Hercules) shot down the eagle with an arrow and released Prometheus from his chains. This myth was addressed by many different old sources, in which Prometheus is either credited or guilty for his challenging knowledge, and ends up being dominated and punished as a result of his arrogance in usurping divine prerogatives. ${ }^{1}$

The myth of Faust, originated in Germany, served as an inspiration for several literary works in different times and countries, of which the most famous is the one by a German writer and thinker who also worked in the field of science, Johann Wolfgang von Goethe (1749-1832). Faust, dissatisfied with the knowledge of his era, accepts damnation in a deal with the devil Mephistopheles, in which he exchanges his soul for a new life. He acquires all the satanic energy to develop his passion for technique and progress in order to make further scientific findings and have eternal life.

However, in his eagerness to master everything, Faust is haunted for the rest of his life. The myth of Faust and its intertext marks acquire a universal meaning as a cultural symbol of modernity, as it materializes the myth of the man who, in the pursuit of power, tends to go out of control and therefore put his own human condition at risk in the process of becoming a universalist. In the Faustian vision, technological domination of nature does not require any human justification that is not the expression of technological power itself, and consequently it has no limits. ${ }^{2}$

The use of the Prometheus and Faust metaphors serves to identify two trends that may be detected as the basis of technoscience development. However, in the dialog between techno- 
topia, which follows the salvific promise, and technophobia, a dystopian eschatological fear, a dichotomy between the two trends is not intended, as they are dissolved in various theories when the topic is addressed, which highlights uncertainties regarding forecasts. ${ }^{3}$ The respective identifications are made in terms of tension in a particular context and in, this study, in the educational context and inter-relations with contemporary ICTs.

\section{The high-tech Pandora's box}

The relationship between technology and society has been the object of broad discussion and controversy. For many centuries, historians and philosophers have perceived and discussed the role of technology in the formation of civilization. For this reflection, it is necessary to consider the process of transformation that emerged from the beginning of modern times and persists into the contemporary era, which was imposed in opposition to the traditional logic that prevailed in the Middle Ages. In this process of transformation, marked by the French and Industrial Revolutions, logic, anthropocentrism, rationality, and the ideals of progress and freedom in science and technology were established.

The modern science currently in place adopts mathematics with its instruments of logic and its model of the representation of matter. To understand means to quantify, which provides the basis for positivist thinking. It is based on Newton's modern mechanism, in which it was possible to understand, master, and explore nature. As a result of the parameters of this scientific model, the traditional paradigm began to be questioned, proving to be insufficient to deal with the insurmountable contradictions, disorder, and uncertainty found by this model itself. ${ }^{4}$

The ingrained vision of the prevailing paradigm of modern science at the time faced strong structural repercussions after research was implemented in different fields of science: the diversity of theoretical, practical, and social conditions ended up changing the whole. From this point of view: "Instead of eternity, history; instead of determinism, unpredictability; instead of mechanism, interpenetration, spontaneity and self-organization; instead of reversibility, irreversibility and evolution, and instead of necessity, creativity and accident". ${ }^{\prime: 48}$

The challenges presented led to an acknowledgment of the need for a complex vision and, in this paradigm shift, to the need to overcome a fragmented, linear, and reductionist vision of the universe. The world is a relationship network that involves connections, interconnections, motion, energy flow, and inter-relations, in a constant process of change and transformation. "In nature, there is no 'above' or 'below,' and there is no hierarchy. There are networks nestled in other networks." ${ }^{5: 45}$ In these paradigmatic transitions, post-modernity is established, a polysemic term that is considered in this work not as a step in the replacement of the modern world, but as a way of questioning various misconceptions that have taken over its construction.

In this context, the traditional NewtonianCartesian paradigm has its misconceptions, but we cannot deny that it enabled the current scientifictechnological development. More than 200 years later, the works of Gottfried Wilhelm Leibniz (1646-1716) influenced mathematical logic and other related fields, such as cybernetics. Artificial language or the narrowing of reasoning to calculations is not a legacy of the $20^{\text {th }}$ century; rather it began in the second half of the $17^{\text {th }}$ century.

In regard to post-modernity, questions that include ICTs and that are supported by the development of computers and Internet stand out. This development was an authentic revolution in society, which plunged into a process of conversion of information that had previously been analogical and printed, but is now made of digital codes that have become a pillar of communication, entertainment, and business in the world. Popularization of the Internet, previously restricted to military and academic institutions in the U.S., erupted across the world, reducing geographical boundaries, strengthening online commerce, and creating spaces for communication and the sharing of opinions. ${ }^{6}$

Currently, the integration of technologies in education, not simply as tools, but as ways of culture and communication, is inevitable, and more than a mere possibility, it appears to be necessary. There is resistance and often fierce criticism; these technologies are perceived, metaphorically, as a true Pandora's box. In Greek mythology, Pandora opened the box given by Zeus and released all the evils into the world, condemning humanity. ${ }^{1}$

However, this Pandora's box needs to be opened; if it is not, it will be impossible to face the tension, paradoxes, and uncertainties regarding digital technologies, and evaluate their relevance in social relations, in production, and especially 
in learning. Otherwise, education will be anachronistic and discordant with students' expectations. These expectations have increased with these technologies, and students' ways of expressing themselves and thinking are different from those of previous generations.

\section{The touchscreen generation and the blackboard revolt}

It is undeniable that the development of ICTs has enabled the flourishing of sciences, philosophy, history, and culture but, at the same time, fatalistic visions appear. This is an era in which haste dictates the rhythm of media, putting reflection aside and strengthening superficiality. The Internet is also a source of misinformation; it is no longer possible to distinguish between voluntary manipulation and involuntary accident. In corporate production, in scientific research, or in armed conflicts, the prevalence of technological resources is currently a model of natural selection.

In this setting we can highlight "mediaphagy," a term used for a social perception in which communication technologies are referred to as if they had divine power. An example is the research engine Google, which is often seen and referred to as omnipresent (present everywhere), omniscient (all-knowing) and omnipotent (all-powerful). ${ }^{7}$

Critics attack digital triumphalism and the culture of multitaskting, which is characteristic of the Internet, considering the Web as a dispersive environment that is changing (for the worse) the way people think and the structure and functioning of the brain itself. The mind of the Internaut, it is argued, is chaotic and polluted; the Internet is harming our cognitive capacity and our way of thinking. In a study on research engines and the Internet, researchers stated that these became an external memory for humans, a sort of "external hard-disk drive." Gradually, computers are becoming responsible for storing personal memories, replacing some brain functions; however, at the same time some researching skills are acquired. ${ }^{9}$

In this apocalyptic vision of ICTs, three ideas are pointed out: that technology is a $20^{\text {th }}$ century addiction; that social networks are superficial; and that research engines are degrading human intelligence. However, discussions generated on the topic indicate that there is no evidence that digital technology has a particular influence on the brain. Changes in the structure and functioning of the brain take place in any learning process, not only as a result of the Internet. Technology may result in addiction and aggression; nevertheless, most important are the benefits that arise with the same processes: learning new abilities; pro-social behavior; and great educational potential. ${ }^{10} \mathrm{As}$ has been pointed out, it is necessary to insist on evaluative and independent techniques, so as to avoid distortions that are disseminated and that will result in rejection and erroneous postulates and interventions.

Historically, technological development has always been accompanied by reluctance. Socrates, who taught through dialog, was opposed to the use of written language, as he argued that it weakened memory and did not allow interaction. During the Industrial Revolution, Luddites invaded English factories to destroy machines and other equipment that were replacing men. Big Brother, in George Orwell's novel 1984, is a pessimistic metaphor about the future of mankind. In universities, technophobic discussions have taken place about whether computers would replace teachers, strengthening their refusal to update themselves. In view of these innovations, different reactions may occur, from extreme acceptance or rejection to lukewarm responses, such as cooperation, resignation, protest, procrastination, or omission. ${ }^{11-13}$

In the educational context, although learning has undergone some global modifications and innovations, it still maintains the same basic orientation and structure as it did in the last century. Currently, digital knowledge is presented as a need, because society is full of digital technologies, and knowledge will be obtained through contact with technologies. The paradigm digital native an individual who was born during the Internet era and who masters different resources - and the digital immigrant - an individual who was born at a time when the Internet was not yet widely used and who has more difficulty in understanding it is no longer relevant, thus making it necessary to focus on the development of these skills. ${ }^{14}$

It is possible to suppose, apart from some exceptions, that teachers would not be comfortable with digital technologies and would be even more reluctant to use them in an educational environment. This dichotomy was criticized, as it prompted a sense of guilt or "technological complex" (Prensky's complex) in which students were seen as superior when using new technological procedures. ${ }^{14}$

However, it is important to note that the students of today are no longer the people for 
whom the educational system was designed. In classrooms, we find students who have known the Internet since their childhood, who are influenced by a fast and complex world of mosaic culture that is ubiquitous and produced by technology. They are natives who speak the digital language. The "touchscreen generation" defined in this study is in line with this generation, who were born immersed in the evolution of ICTs and connected to the Web via their smartphones, personal computers, tablets, and iPods, among others. Today they prefer the interactive white board, with the Internet, videos, animations, games, and other applications, a new concept that is different than the traditional blackboard.

Traditional pedagogical practices are somewhat obsolete. Strictly institutionalized education, with a linear and hierarchical way of transmitting knowledge, does not make sense anymore, and the educational spectrum must be broadened, because education is no longer represented by formality in a classroom, and many other spaces need to be explored, such as cyberspace.

In this mobile space of interaction between knowledge and experts, barriers of time and space are overcome; exodus and deterritorialization occur, interconnecting contexts, subjects, and knowledge in a non-linear flow and with diverse practices. ${ }^{6}$ There is a new poetical imagery and a hybridization of genders, a heterogenesis that questions uniformity and fixity. Information begins to be available in networks and to be shared.

Information highways are characterized as vehicles of democratic access, as they convert walls into bridges, requiring a watchful and critical eye on the part of the user. In the profusion of the information flow and the emerging chaos, the Internet has its own means of control: public opinion. In a reinforcement of the concept of the "public sphere," the argument of authority cannot occupy and dominate the setting anymore. In the collaborative process, joint work makes it possible for everyone to have the opportunity to develop and improve their knowledge. ${ }^{15}$

In view of this, among the challenges that teachers have to face is the production of quality material for educational purposes. Nursing professionals have difficulties in dealing with and assessing tools made available by ICTs, and IT professionals have difficulties in dealing with the pedagogical issues of tools developed for educational purposes. Proposals and comprehensive actions are necessary; otherwise, there will be an increasing gap between possibilities and mismatched demands.

Didactic-pedagogical strategies, which include multimedia and hypermedia, may not ensure pedagogical quality because they still follow the traditional instruction and unilateral model to the detriment of the reflexive and creative aspects made possible by these tools. The simple digitalization of the didactic-analogical material underestimates the potential of digital technologies, and inequalities between technical and pedagogical factors limit the strategies of action for learners. ${ }^{14-15}$ To buy an island in "Second Life" and to give a training course there does not mean that it will be effective and of good quality. Actually, in the new media, old methods still exist.

Contemporary ICTs allow for creative learning processes for nursing with innovative pedagogical proposals that make meaningful learning possible, ${ }^{16-19}$ either in undergraduate, extension, and graduate courses, or in laboratories, classrooms, or distance-learning, in which sharing with other institutions is possible. Currently, the development of mobile application technology, focused on health and education, provides a fertile ground for nursing performance within the community as a whole. ${ }^{20-22}$ Mobile technology will play a key role in the provision of health care and support services at a global level. An essential tool serves not only to inform and control diseases, but also to prevent and control potential epidemics.

In Brazil, the Ministry of Education (MEC), in partnership with the Ministry of Science and Technology (MCT), the Latin American Network of Education Portals (RELPE), the Organization of Ibero-American States (OEI), and Brazilian universities created the International Database of Educational Objects (BIOE), a repository that makes digital educational resources available, in open access, in different languages and formats, for educational use according to the various levels of learning, and subsidizing different pedagogical practices.

Quick innovations certainly require a broad debate in order to avoid extreme visions and will require skills for their implementation, and nursing professionals must be aware of these issues. ${ }^{23}$ Investments in support for teachers are necessary, and making means available is not sufficient; it is also necessary to understand the mediating potential of media languages and of the resources for creation and publication provided by these technologies. Tools are no longer seen simply 
as tools, but go beyond instrumentation and are considered as structuring elements that allow converting information into knowledge towards a proactive citizenship. Other challenges arise in regard to teachers, students, and the community as a whole and they cannot be neglected; it is important to implement effective public policies that contribute to digital inclusion in the most comprehensive way, making sure that these three pillars - ICTs, income, and education - are safe.

\section{CONCLUSIONS}

Inevitable and irreversible, ICTs require active insertions and redefinitions in the work processes of nursing teachers and students in order to comply with the current educational reality. However, change is something extremely complex, due to resistance and the need to assimilate the unknown and, in this deadlock of incongruity that involves the technology issue, it is already possible to observe the ambiguity and the issues in its theoretical construction. Concepts vary and are founded according to personal interpretations, ethnic-cultural background, and political-ideological idiosyncrasies, among other less tangible factors. It is important to avoid either a vision of technotopia, in which technology is the solution for everything, or technophobia, in a dystopian sense, fearing that one day a terrorist attack will destroy the servers in which all human memory is stored and, as a consequence, all of the history of mankind will be lost.

ICTs and their educational interfaces in nursing represent an excellent opportunity to deepen interdisciplinary dialogs. Establishing pedagogical mediation between the different forms of hypermedia languages is relevant and, in that sense, it is necessary to undo the conceptual knots and go beyond the instrumentalist and deterministic conceptions that follow them. After all, in a world of broadband, smartphones, e-books, distancelearning, games, and educational applications, and the collaborative social networks and many other novelties that surface every day, the use of technology appears as an ally in the education process. The important thing is to be a critical, creative, and active user, and to do that it is necessary to sail the seas of radical changes.

\section{REFERENCES}

1. Hesiodo. Teogonia: a origem dos deuses. Werner $C$, tradutor. São Paulo (SP): Hedras; 2013.
2. Goethe WJ. Fausto II. Segall JK, tradutor. São Paulo (SP): Editora 34; 2011.

3. Martins H. Experimentum humanum: civilização tecnológica e condição humana. Lisboa (PT): Relógio D'Água Editores; 2011.

4. Santos BS. Um discurso sobre as ciências. $7^{\mathrm{a}}$ ed. São Paulo (SP): Cortez; 2010.

5. Capra F. A teia da vida. $12^{a}$ ed. São Paulo (SP): Cultrix; 2010.

6. Lévy P. Cibercultura. Costa IC, tradutor. $3^{\mathrm{a}}$ ed. São Paulo (SP): Editora 34; 2010.

7. Miklos JA. Construção de vínculos religiosos na cibercultura: a ciber-religião [tese]. São Paulo (SP): Pontifícia Universidade Católica, Programa de PósGraduação em Comunicação e Semiótica; 2010.

8. Carr N. The Shallows: what the Internet is doing to our brains. New York (US): WW Norton \& Company; 2010.

9. Sparrow B, Liu J, Wegner DM. Google effects on memory: cognitive consequences of having information at our fingertips. Science [online]. 2011 [acesso 2014 Jan 6]; 333(6043):776-8. Disponível em: http://www.sciencemag.org/ content/333/6043/776.abstract

10. Jones $\mathrm{PH}$. What is the Internet doing to our brains? [webconference]. London (UK): RSA; 2011 [acesso 2014 Fev 28]. Disponível em: http://www.thersa. org/events/video/archive/dr-paul-howard-jones

11. Nilsson L, Eriksén S, Borg C. Social challenges when implementing information systems in everyday work in a nursing context. Comput Inform Nurs. 2014 Sep; 32(9):442-50.

12. While A, Dewsbury G. Nursing and information and communication technology (ICT): a discussion of trends and future directions. Int J Nurs Stud. 2011 Oct; 48(10):1302-10.

13. Brewster L, Mountain G, Wessels B, Kelly C, Hawley M. Factors affecting front line staff acceptance of telehealth technologies: a mixed-method systematic review. J Adv Nurs. 2014 Jan; 70(1):21-33.

14. Prensky M. From digital natives to digital wisdom: hopeful essays for 21st Century Learning. USA: Corwin; 2013.

15. Tapscott D, Williams AD. Wikinomics: how mass collaboration changes everything. USA: Penguin Group; 2010.

16. Fonseca LM, Dias DM, Góes FS, Seixas CA, Scochi CG, Martins JC, et al. Development of the e-Baby serious game with regard to the evaluation of oxygenation in preterm babies: contributions of the emotional design. Comput Inform Nurs. 2014 Sep; 32(9):428-36.

17. NI 2014: Nursing Informatics 2014 - Proceedings of the 12th International Congress on Nursing Informatics [online], Taiwan: 2014 [acesso 2014 Jul 25]. Disponível em: http://ebooks.iospress. 
$\mathrm{nl} /$ volume/nursing-informatics-2014-east-meetswest-esmart

18. Beach SN, Hall RL. The connected educator: learning and leading in a digital age. Bloomington (UK): Solution Tree Press; 2012.

19. Galvão E, Correia F, Püschel VAA. Aplicativo multimídia em plataforma móvel para o ensino da mensuração da pressãovenosa central. Rev Esc Enferm [online]. 2012 [acesso 2014 Jan 26]; 46(Esp):: Disponível em: http:/ / www.scielo.br/scielo.php?script=sci_ arttext\&pid=S0080-62342012000700016

20. Gellis ZD, Kenaley BL, Ten Have T. Integrated telehealth care for chronic illness and depression in geriatric home care patients: the Integrated Telehealth Education and Activation of Mood (I-TEAM) study.
J Am Geriatr Soc. 2014 May; 62(5):889-95.

21. Haze KA, Lynaugh J. Building patient relationships: a smartphone application supporting communication between teenagers with asthma and the $\mathrm{RN}$ care coordinator. Comput Inform Nurs. 2013 Jun; 31(6):266-71.

22. Sad SN, Gekas O. Preservice teachers' perceptions about using mobile phones and laptops in education as mobile learning tools. B J Educ Technol. $2014 \mathrm{Jul}$ : 45(4):606-18.

23. Lorenzetti J, Trindade LL, Pires D, Pires ED, Ramos FRS. Tecnologia, inovação tecnológica e saúde: uma reflexão necessária. Texto Contexto Enferm [online]. 2012 [acesso 2014 Jan 09]; 21(2):. Disponível em: http://www.scielo.br/scielo.php?script=sci_ arttext\&pid=S0104-07072012000200023 